\title{
ANALISIS PENGARUH KINERJA KEUANGAN TERHADAP HARGA SAHAM PT. INDOFOOD SUKSES MAKMUR, TbK DI BURSA EFEK INDONESIA (BEI) TAHUN 2014-2018
}

\author{
ANALYSIS OF FINANCIAL PERFORMANCE EFFECT ON \\ STOCK PRICE PT. INDOFOOD SUKSES MAKMUR, TbK \\ IN THE STOCK EXCHANGE OF INDONESIA (IDX) 2014-2018
}

\author{
Pra Gemini \\ STIEM LPI MAKASSAR \\ Correspondenence Author: pragemini@gmail.com
}

\begin{abstract}
Financial performance is one of the internal factors that affect the stock price of a Go Public company. This study aims to determine the effect of financial performance on stock prices at PT. Indofood Sukses Makmur, Tbk on the IDX with a period of 5 years (2014-2018). This research is an associative research in the form of causality. Sampling in this study using documentation techniques to obtain 5 research samples. The data used is taken from financial statements issued by the IDX and the share price is obtained from finance.yahoo.com. Data analysis uses Multiple Linear Regression analysis. The results showed that partially variable CR does not affect and are not significant to the price of the stock at $\alpha=0,05$. GPM has no effect and is not significant on stock at $\alpha=0,05$. NPM variable has posititive and significant efffect on stock prices at $\alpha=0,05$. The coefficient of determination (R2) in this study was 0.981, which means the ability of the independent variable in explaining the variation of the dependent variable was $98.1 \%$ while the remaining $1.9 \%$ was explained by other independent variables outside the model.
\end{abstract}

Keywords: Stock Prices, Current Ratio, Gross Profit Margin, Net Profit Margin.

\begin{abstract}
ABSTRAK
Kinerja keuangan merupakan salah satu faktor internal yang mempengaruhi harga saham perusahaan Go Public. Penelitian ini bertujuan untuk mengetahui pengaruh kinerja keuangan terhadap harga saham pada PT. Indofood Sukses Makmur, Tbk di BEI dengan kurun waktu selama 5 tahun (2014-2018). Penelitian ini merupakan penelitian asosiatif yang berbentuk kausalitas. Pengambilan sampel dalam penelitian ini menggunakan teknik dokumentasi sehingga diperoleh 5 sampel penelitian. Data yang digunakan diambil dari laporan keuangan yang diterbitkan oleh BEI dan harga saham diperoleh dari finance.yahoo.com. Analisis data menggunakan analisis Regresi Linear Berganda. Hasil penelitian menunjukkan bahwa secara parsial variabel CR tidak berpengaruh dan tidak signifikan terhadap harga saham pada $\alpha=0,05$. GPM tidak berpengaruh dan tidak signifikan terhadap harga saham pada $\alpha=0,05$. Variabel NPM berpengaruh positif dan signifikan terhadap harga saham pada $\alpha=0,05$. Nilai koefisien determinasi (R2) dalam penelitian ini sebesar 0,981 yang artinya kemampuan variabel bebas dalam menjelaskan variasi variabel terikat sebesar $98,1 \%$ sedangkan sisanya sebesar $1,9 \%$ dijelaskan oleh variabel bebas lain diluar model.
\end{abstract}

Kata Kunci: Harga Saham, Current Ratio, Gross Profit Margin, Net Profit Margin. 


\section{PENDAHULUAN}

Salah satu instrument keuangan yang diperjuabelikan pada pasar modal adalah saham. Saham dapat didefinisikan sebagai tanda penyertaan atau kepemilikan seseorang atau badan dalam suatu perusahaan atau perseroan terbatas. Wujud saham adalah selembar kertas yang menerangkan bahwa pemilik kertas tersebut adalah pemilik perusahaan yang menerbitkan surat berharga tersebut. Porsi kepemilikan ditentukan oleh seberapa besar penyertaan yang ditanamkan di perusahaan tersebut (Darmadji dan Fakhruddin, 2001:5). Dengan menjual sahamnya maka perusahaan harus berbagi kepemilikan dengan para pemegang saham atau biasa disebut dengan stockholder.

$$
\text { Dengan berbagi kepemilikan }
$$

perusahaan, maka laba yang didapat juga harus dibagi dengan para stockholder yang secara umum dikenal dengan dividen. Pengertian saham yang lainnya adalah tanda penyertaan atau pemilikan seseorang atau badan dalam suatu perusahaan (Fakhruddin dan Hadianto, 2001: 6). Sedangkan menurut Simamora (2000:408), saham memberikan indikasi kepemilikan atas perusahaan sehingga para pemegang saham berhak menentukan arah kebijaksanaan perusahaan lewat Rapat Umum Pemegang Saham (RUPS). Para pemegang saham juga berhak memperoleh deviden yang dibagikan oleh perusahaan. Sebaliknya, pemegang saham juga turut menanggung resiko sebesar saham yang dimiliki apabila perusahaan tersebut bangkrut.

Pada perdagangan efek khususnya saham, informasi memiliki peranan yang dominan dan krusial. Suad Husnan (2004) menyebutkan bahwa sebuah pasar modal dikategorikan efisien jika harga sekuritasnya telah mencerminkan semua informasi yang relevan. Semakin cepat informasi terefleksikan pada harga sekuritas maka pasar modal tersebut semakin efisien. Investor dalam menanamkan modalnya berharap untuk memperoleh return saham yang sebesar-besarnya.

Analisis fundamental membandingkan antara nilai intrinsik suatu saham dengan harga pasarnya guna menentukan apakah harga saham tersebut sudah mencerminkan nilai intrinsiknya. Ide dasar pendekatan ini adalah bahwa harga saham dipengaruhi oleh kinerja perusahaan. Kinerja perusahaan itu sendiri dipengaruhi oleh kondisi industri dan perekonomian secara makro (Abdul Halim dalam Raden Tinneke, 2007).

Beberapa penelitian tentang pengaruh kinerja keuangan terhadap harga saham telah dilakukan Adhitya Wicaksono (2013) terdapat pengaruh Current Ratio, Debt to Assets Ratio, Total Assets Turnover, Return On Equity, Suku Bunga, Kurs Valuta Asing, Inflasi, dan Kas Dividen terhadap Harga Saham Perusahaan Makanan dan Minuman yang Terdaftar di BEI Periode 2009-2011.

Penelitian yang dilakukan oleh Achmad Husaini (2012), hasil dari penelitian ini menunjukkan bahwa kinerja keuangan perusahaan yang diukur dari ROA, ROE, NPM, dan EPS mempunyai pengaruh terhadap harga saham. Secara parsial bahwa variabel ROA dan EPS yang berpengaruh secara signifikan terhadap harga saham. Sedangkan variabel ROE dan NPM tidak berpengaruh secara signifikan terhadap harga saham. ROA mempunyai pengaruh dominan terhadap harga saham pada perusahaan yang termasuk dalam perusahaan Food and Beverages.

Tiara Rachman Putri (2011) dalam penelitiannya bahwa hasil pengujian secara parsial/uji t menunjukkan variabel Return On Asset (ROA) dan Earning Per Share (EPS) berpengaruh positif terhadap harga saham dan memiliki konstribusi dominan terhadap harga saham. Pengujian uju regresi secara simultan/uji F menunjukkan variabel bebas (CR, DER, ROA, ROE, dan EPS) secara simultan (bersama-sama) berpengaruh secara signifikan terhadap harga saham. 
Firman Maulana (2014) dalam penelitian bahwa CR, DER, dan NPM mempunyai pengaruh yang signifikan terhadap harga saham, Andrarini (2007) dalam penelitiannya tentang pengaruh kinerja keuangan yang diukur dengan rasio keuangan terhadap harga saham pada perusahaan manufaktur yang terdaftar di BEJ periode 2003-2005 dengan variabel yang terdiri dari ROI, ROE, DER, CR, NPM dan variabel terikatnya adalah harga saham. Penelitian ini menyimpulkan bahwa secara simultan rasio keuangan ROI, ROE, DER, CR, dan NPM berpengaruh signifikan positif terhadap harga saham, sedangkan hasil pengujian secara parsial menunjukkan rasio keuangan ROI, ROE, dan NPM berpengaruh positif signifikan terhadap harga saham.

Nieke Arwiyati Shidiq (2012) dalam penelitiannya bahwa EVA dan EPS berpengaruh positif dan signifikan terhadap harga saham sedangkan Return on Equity (ROE) dan Return on Sales (ROS) berpengaruh negatif tidak signifikan terhadap harga saham dan Return on Asset (ROA) berpengaruh positif tidak signifikan terhadap harga saham.

\section{MATERI DAN METODE}

Tempat yang digunakan untuk memperjual belikan berbagai instrumen keuangan tersebut adalah bursa efek (arti dari pasar modal secara fisik). Di Indonesia saat ini ada satu bursa efek yang beroperasi, yaitu Bursa Efek Indonesia (BEI) yang terletak di Jakarta. .Porsi kepemilikan ditentukan oleh seberapa besar penyertaan yang ditanamkan di perusahaan tersebut (Darmadji dan Fakhruddin, 2001:5). Dengan menjual sahamnya maka perusahaan harus berbagi kepemilikan dengan para pemegang saham atau biasa disebut dengan stockholder. Dengan berbagi kepemilikan perusahaan, maka laba yang didapat juga harus dibagi dengan para stockholder yang secara umum dikenal dengan dividen. Para pemegang saham juga berhak memperoleh deviden yang dibagikan oleh perusahaan. Sebaliknya, pemegang saham juga turut menanggung resiko sebesar saham yang dimiliki apabila perusahaan tersebut bangkrut.

Laporan keuangan merupakan sarana yang penting bagi investor untuk mengetahui perkembangan perusahaan secara periodik (Muhammad Samsul, 2006: 128). Laporan keuangan memberikan informasi mengenai kondisi perusahaan dan hasil operasi perusahaan yang pada hakikatnya merupakan hasil akhir dari kegiatan akuntasi perusahaan yang bersangkutan.

Menurut Brigham dan Houston (2013) ada lima rasio keuangan yang dapat digunakan untuk menganalisis harga saham yaitu Rasio Likuiditas, Rasio Solvabilitas Rasio Profitabilitas atau Rentabilitas. Sedangkan menurut Abdul Halim (2005: 5) untuk melakukan analisis terhadap suatu efek atau kelompok efek tentang harga yang terlalu tinggi atau terlalu rendah ada 2 pendekatan yaitu pendekatan teknikal dan pendekatan fundamental. Laporan keuangan suatu perusahaan Go Public terdiri dari empat laporan keuangan, yaitu neraca, laporan laba/rugi, laporan perubahan modal, dan laporan arus kas. Di dalam laporan keuangan tersebut, terdapat tiga rasio keuangan yang biasa digunakan untuk menganalisis faktor apa saja yang mempengaruhi harga saham. Ketiga rasio tersebut diantaranya adalah rasio likuiditas, rasio solvabilitas dan rasio profitabilitas/rentabilitas.

Untuk melihat bagaimana pengaruh dari masing-masing variabel terhadap harga saham dapat dijelaskan sebagai berikut: 1) Current ratio menunjukkan seberapa besar nilai aktiva lancar dapat menutupi besarnya harta lancar. Current ratio merupakan salah satu rasio yang digunakan untuk mengukur likuiditas perusahaan. Jika likuiditas perusahaan lemah akan menghalangi perusahaan untuk mendapatkan keuntungan yang nantinya akan mengakibatkan menurunnya laba yang dihasilkan oleh perusahaan. Jika current ratio rendah maka akan terjadi penurunan pada harga pasar saham pada perusahaan tersebut. Begitu juga 
sebaliknya, apabila current ratio yang terlalu tinggi, itu juga tidak terlalu baik, karena hal tersebut mengindikasikan kemampuan perusahaan dalam mendapatkan laba kurang maksimal terbukti adanya akitivitas yang dilakukan oleh perusahaan sedikit. Dapat disimpulkan bahwa ketika current ratio yang tinggi dapat memperlihatkan bahwa harga saham juga akan tinggi dan sebaliknya jika current ratio yang semakin rendah mengindikasikan harga saham rendah; 2) Operating profit margin merupakan rasio yang mengukur kemampuan untuk meningkatkan laba sebelum bunga dan pajak dengan penjualan yang dicapai perusahaan, dalam pengertian bahwa jumlah tersebutlah yang benar-benar diperoleh dari hasil operasi perusahaan dengan mengabaikan kewajibankewajiban finansial berupa bunga serta kewajiban terhadap pemerintah berupa pajak. Semakin tinggi operating profit margin akan semakin baik pula operasi suatu perusahaan. Net profit margin merupakan ratio antara laba bersih yaitu penjualan sesudah dikurangi dengan seluruh expenses termasuk pajak dibandingkan dengan penjualan, dimana kemampuan perusahaan mendapatkan laba melalui semau kemampuan dan seumber yang ada. Semakin tinggi net profit margin, maka semakin baik operasi suatu perusahaan; 3) Beberapa variable yang digunakan dalam penelitian yaitu Rasio lancar adalah rasio yang menunjukkan seberapa besar tagihan jangka pendek dari kreditur yang dapat dipenuhi dengan aktiva lancar yang diharapkan dapat dikonversi menjadi kas dalam waktu dekat, Gross Profit Margin (GPM), yaitu rasio untuk mengukur kemampuan perusahaan dalam mendapatkan laba kotor dari penjualan, Net Profit Margin (NPM), yaitu rasio untuk mengukur kemampuan perusahaan dalam mendapatkan laba bersih dari penjualan.

Penelitian ini merupakan penelitian asosiatif yang berbentuk kausalitas. Pengambilan sampel dalam penelitian ini menggunakan teknik dokumentasi sehingga diperoleh 5 sampel penelitian. Data yang digunakan diambil dari laporan keuangan yang diterbitkan oleh BEI dan harga saham diperoleh dari finance.yahoo.com. Sampel dalam penelitian ini adalah Laporan keuangan Tahunan PT. Indofood Sukses Makmur selama periode tahun penelitian 2014-2018. Harga saham Tahunan PT. Indofood Sukses Makmur, Tbk selama periode tahun penelitian 2014-2018.

Analisis regresi berganda digunakan untuk mengetahui apakah rasio keuangan yang merupakan variabel bebas dapat mengukur tingkat harga saham. Analisis ini untuk menunjukkan pengaruh antara kinerja keuangan yang diproksikan dengan rasio $\mathrm{CR}$ $\left(\mathrm{X}_{1}\right)$, GPM $\left(\mathrm{X}_{2}\right)$, NPM $\left(\mathrm{X}_{3}\right)$. Adapun kerangka pemikiran berkut ini:

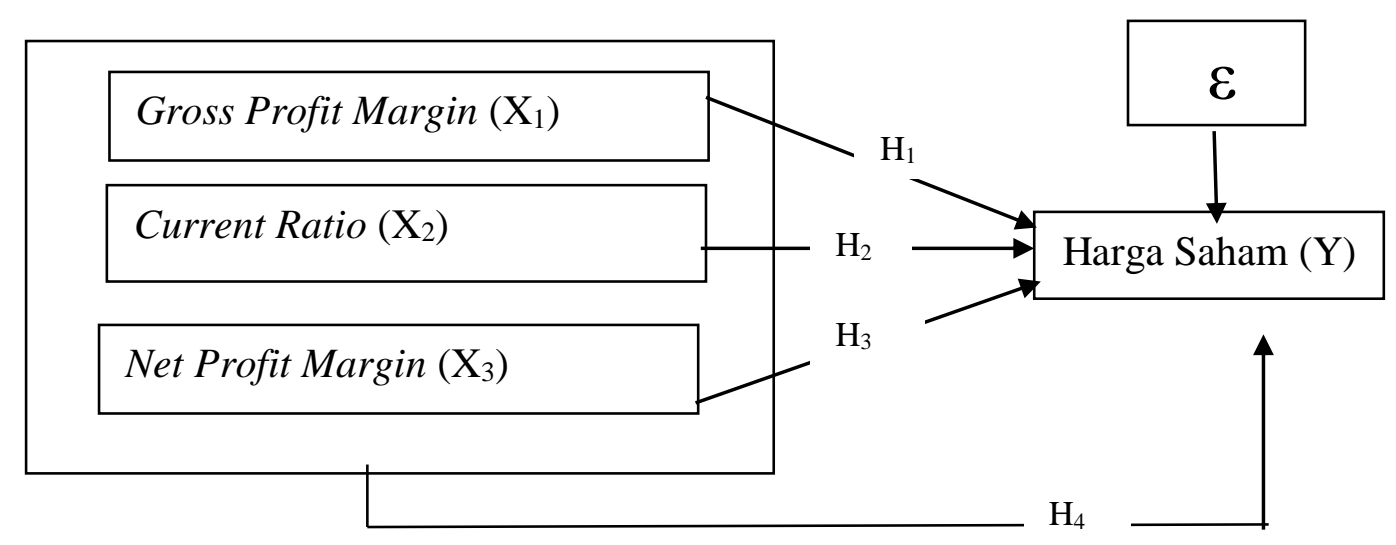

Gambar 1. Kerangka Pemikiran 


\section{Hipotesis dalam penelitian ini adalah}

\section{$\mathrm{H}_{1}$ : Gross Profit Margin (GPM) berpengaruh secara parsial terhadap harga saham PT.Indofood Sukses Makmur, Tbk.}

$\mathrm{H}_{2}$ : Gross Profit Margin (GPM) berpengaruh secara parsial terhadap harga saham PT.Indofood Sukses Makmur, Tbk.

$\mathrm{H}_{3}$ : Gross Profit Margin (GPM) berpengaruh secara parsial terhadap harga saham PT.Indofood Sukses Makmur, Tbk.

$\mathrm{H}_{4}$ : Gross Profit Margin (GPM) berpengaruh secara parsial terhadap harga saham PT.Indofood Sukses Makmur, Tbk.

\section{HASIL PENELITIAN}

\section{Uji Asumsi Klasik}

Hasil uji yaitu a) Uji normalitas bahwa data dinyatakan terdistribusi normal; b) Uji multikolonieritas tidak multikoloni antara variabel bebasnya; c) Uji heterokedastisitas tidak heterokedastisitas dari semua model regresi; d) Uji autokolerasi tidak terdapat gejala atau masalah autokorelasi. Dengan demikian, masalah autokrelasi yang tidak dapat terselesaikan dengan durbin Watson dapat teratasi melalui uji run test sehingga analisis regeresi berganda dapat dilanjutkan.

\section{Hasil Pengolahan Data}

Analisis data memakai SPSS type 22.0 diperoleh hasil persamaan berikut:

Tabel Rangkuman Hasil Perhitungan Current Ratio (CR), Gross Profit Margin (GPM) dan Net Profit Margin (NPM) Terhadap Harga Saham

\begin{tabular}{|c|c|c|c|c|c|}
\hline \multirow{2}{*}{ Model } & \multicolumn{2}{|c|}{ Unstandardized Coefficients } & \multirow{2}{*}{$\begin{array}{c}\begin{array}{c}\text { Standardized } \\
\text { Coefficients }\end{array} \\
\text { Beta }\end{array}$} & \multirow{2}{*}{$\mathbf{t}$} & \multirow{2}{*}{ Sig. } \\
\hline & B & Std. Error & & & \\
\hline (Constant) & $-5838,512$ & 7626,528 & &,- 766 &, 584 \\
\hline GPM & 371,981 & 259,089 & ,322 & 1,436 & ,387 \\
\hline $\mathrm{CR}$ & $-20,811$ & 9,493 &,- 490 & $-2,192$ & 272 \\
\hline NPM & 16,560 & ,639 & ,971 & 25,909 & 000 \\
\hline F-hitung & $=17,313$ & & & & \\
\hline Sig & $=.000$ & & & & \\
\hline $\mathrm{R}$ & $=, 991$ & & & & \\
\hline $\mathrm{R}^{2}$ & $=, 981$ & & & & \\
\hline Adjusted $\mathrm{R}^{2}$ & $=, 924$ & & & & \\
\hline Alpha $(\alpha)$ & $=5 \%$ & & & & \\
\hline
\end{tabular}

Sumber: Data Diolah, 2019.

Nilai konstanta sebesar : $(5838,512)$; menunjukkan bahwa ketika $X_{1}, X_{2}$ dan $X_{3}=$ 0 , maka harga saham (Y) nilainya sebesar $(5838,512)$, Koefisien regresi variabel $\mathrm{X}_{1}$ sebesar 371,981; artinya apabila $\mathrm{X}_{1}$ mengalami kenaikan 1\%, maka nilai GPM akan mengalami kenaikan sebesar 371,981; dengan asumsi variabel independen lain nilainya konstan, Koefisien regresi variabel $\mathrm{X}_{2}$ sebesar $(20,811)$; artinya apabila $\mathrm{X}_{2}$ dinaikkan $1 \%$, maka nilai $\mathrm{CR}$ mengalami penurunan sebesar 20,811; dengan asumsi bahwa variabel independen lain nilainya tetap, Koefisien regresi variabel $\mathrm{X}_{3}$ sebesar
16,560; artinya apabila $\mathrm{X}_{3}$ mengalami kenaikan 1\%, maka nilai NPM akan mengalami kenaikan sebesar 16,560 dengan asumsi variabel independen lain nilainya konstan.

Besarnya angka koefisien determinasi $R$ Square adalah 0,981 atau sama dengan 98,1\%. Angka tersebut mengandung arti bahwa variable CR, GPM dan NPM berpengaruh terhadap variable Y (Harga Saham) sebesar 98,1\%. Sedangkan sisanya $(100 \%-98,1 \%=1,9 \%)$ dipengaruhi oleh variable lain diluar persamaan regresi ini atau variable yang tidak diteliti. 
Berdasarkan hasil estimasi pada tabel coefficient dapat dijelaskan mengenai pengujian hipotesis dari masing-masing variabel bebas yaitu Berdasarkan hasil estimasi variabel GPM memiliki nilai signifikansi sebesar 0,387. Nilai signifikansi GPM 0,387 > 0,05 menunjukkan bahwa variabel GPM tidak berpengaruh terhadap harga saham. Berdasarkan hipotesis yang diajukan menerima Ho yang artinya secara statistik GPM tidak mempengaruhi harga saham, Berdasarkan hasil estimasi variabel CR memiliki nilai signifikansi sebesar 0,272. Nilai signifikansi CR $0,272>0,05$ menunjukkan bahwa variabel $\mathrm{CR}$ tidak berpengaruh terhadap harga saham. Berdasarkan hipotesis yang diajukan menerima Ho yang artinya secara statistik CR tidak mempengaruhi harga saham, Nilai signifikansi GPM 0,387 < 0,05 menunjukkan bahwa variabel GPM tidak berpengaruh terhadap harga saham. Berdasarkan hasil estimasi variabel NPM memiliki nilai signifikansi sebesar 25,909. Nilai signifikansi NPM 0,000 <0,05 menunjukkan bahwa variabel NPM berpengaruh terhadap harga saham. Berdasarkan hipotesis yang diajukan menolak Ho yang artinya secara statistik NPM mempengaruhi harga saham.

Berdasarkan hasil estimasi pada table Annova menunjukkan nilai signifikansi $0,000<0,05$ menunjukkan bahwa secara simultan variabel bebas berpengaruh terhadap harga saham. Analisis data dan pengujian hipotesis yang dilakukan dalam penelitian ini, maka dapat diketahui bahwa Current Ratio (CR) berpengaruh negative terhadap harga saham PT. Indofood Sukses Makmur, Tbk. Hal ini dibuktikan dengan hasil nilai signifikansi $0,272>0,05$. Hasil penelitian ini mendukung hasil penelitian Teska Destia Ratri (2015) menyatakan bahwa CR tidak berpengaruh terhadap harga saham. CR menunjukkan seberapa besar kemampuan perusahaan dalam melunasi hutang jangka pendeknya. Tidak ada ketentuan yang mutlak tentang berapa tingkat $\mathrm{CR}$ yang dianggap baik atau yang harus dipertahankan oleh suatu perusahaan.
Namun standar umum yang digunakan untuk mengukur CR perusahaan yang baik berada pada batas $200 \%$. Jika CR suatu perusahaan diatas $200 \%$ (terlalu likuid) maka perusahaan tersebut mempunyai kas yang menganggur dalam jumlah besar. Hal tersebut mengindikasikan tidak efisiennya pengelolaan kas. Ketika CR perusahaan rendah artinya perusahaan dalam posisi kesulitan keuangan karena pada suatu saat perusahaan harus membayar hutang jangka pendeknya. Biasanya baik buruknya CR ini juga sangat tergantung kepada jenis usaha dari masing-masing perusahaan. $\mathrm{CR}$ yang tidak signifikan menujukkan bahwa setiap perubahan $\mathrm{CR}$ tidak berpengaruh terhadap perubahan harga saham. Hal ini menunjukkan bahwa investor yang ingin berinvestasi dalam saham tidak perlu memperhatikan nilai CR.

Berdasarkan analisa data dan pengujian hipotesis yang dilakukan dalam penelitian ini, maka dapat diketahui bahwa Gross Profit Margin (GPM) tidak berpengaruh terhadap harga saham PT. Indofood Sukses Makmur, Tbk. Hal ini dibuktikan dengan hasil nilai signifikansi $0,387>0,05$. GPM menunjukkan bahwa perusahaan mampu menekan beban pokok penjualan, sehingga perusahaan bisa menghasilkan laba kotor yang tinggi. Nah laba kotor yang tinggi akan meningkatkan rasio GPM jika presentasi kenaikannya setiap tahun bisa lebih besar daripada kenaikan penjualan bersih. Berdasarkan Rasio GPM, perusahaan yang baik adalah perusahaan yeng memiliki rasio GPM yang tinggi, atau Rasio GPM nya cenderung naik atau stabil untuk setiap tahun. Namun Rasio GPM pada PT. Indofood Sukses Makmur, Tbk., cenderung rendah atau tidak stabil tiap tahunnya sehingga tidak berpengaruh terhadap harga sahamnya.

Berdasarkan analisa data dan pengujian hipotesis yang dilakukan dalam penelitian ini, maka dapat diketahui bahwa Net Profit Margin (NPM) berpengaruh terhadap harga saham PT. Indofood Sukses Makmur, Tbk. Hal ini dibuktikan dengan 
hasil nilai signifikansi $0,000>0,05$. NPM menunjukkan perbandingan antara laba bersih dan pendapatan operasional perusahaan. Saat laba bersih naik, total penjualan pun akan naik hal ini disebabkan karena tingginya biaya yang dikeluarkan sehingga Net Profit Margin pada PT. Indofood Sukses Makmur, Tbk memiliki pengaruh terhadap harga sahamnya.

\section{KESIMPULAN DAN IMPLIKASI}

Current Ratio (CR) adalah rasio yang menggambarkan kemampuan perusahaan dalam memenuhi kewajiban jangka pendeknya. Dari hasil uji dapat disimpulkan bahwa $\mathrm{CR}$ mempunyai pengaruh negative dan tidak signifikan. CR yang tidak signifikan menujukkan bahwa setiap perubahan $\mathrm{CR}$ tidak berpengaruh terhadap perubahan harga saham. Hal ini menunjukkan bahwa investor yang ingin berinvestasi dalam saham tidak perlu memperhatikan nilai CR.

Pengaruh Gross Profit Margin (GPM) terhadap harga saham adalah negative dan tidak signifikan. Pengaruh negative menunjukkan bahwa pengaruh Gross Profit Margin (GPM) adalah tidak searah dengan harga saham atau dengan kata lain Gross Profit Margin (GPM) yang kurang baik/tidak stabil tidak mempengaruhi harga saham.

$$
\text { Net Profit Margin (NPM) }
$$

menunjukkan perbandingan antara laba bersih dan pendapatan operasional perusahaan. Dari hasil uji dapat disimpulkan bahwa NPM mempunyai pengaruh positif dan signifikan terhadap harga saham PT. Indofood Sukses Makmur, Tbk., Hal ini disebabkan karena margin laba perusahaan yang tiap tahunnya stabil atau dapat dikatakan baik.Sedangkan implikasinya perusahaan sebaiknya memperhatikan jumlah hutang dan modal yang dimiliki perusahaan karena jika jumlah hutangnya terlalu besar sedangkan modalnya kecil akan membuat beban perusahaan terhadap pihak luar semakin besar. Ketika beban perusahaan terhadap pihak luar besar menunjukkan bahwa perusahaan sangat bergantung kepada pihak luar yang nantinya akan menurunkan minat investor dalam menamkan dananya dan berdampak pada harga saham perusahaan tersebut. Perusahaan sebaiknya memperhatikan laba bersih perusahaan yang nantinya akan digunakan sebagai acuan para investor dalam pengambilan keputusan untuk menginvestasikan dananya. persediaannya yang nantinya akan berdampak pada pendapatan perusahaan dan juga berdampak pada laba perusahaan yang nantinya juga berdampak pada harga saham.

\section{UCAPAN TERIMAKASIH}

Ucapan terimakasih kepada PT. Indofood Sukses Makmur, Tbk.

\section{DAFTAR PUSTAKA}

Abdul Halim dalam Raden Tinneke. 2007. Pengaruh Economic Value Added, Risiko Sistematis, Dan Prediksi Kebangkrutan Dengan Model Altman Z-Score Terhadap Return Saham (Perusahaan Lembaga Keuangan yang Terdaftar Di BEI) Tahun 20072011.

Achmad, Husaini. 2012. Pengaruh Variabel Return on Assets, Return on Equity, Net Profit Margin dan Earning Per Share Terhadap Harga Saham Perusahaan. Jurnal Profit. Universitas Brawijaya.

Akifa P Nayla. 2013. Cara Praktis Menyusun Laporan Keuangan. Jogjakarta. Laksana.

Andrarini. 2007. Pengaruh Kinerja Keuangan yang Diukur Dengan Rasio Keuangan Terhadap Harga Saham Pada Perusahaan Manufaktur yang Terdaftar di BEJ Periode 2003-2005.

Brigham, Weston. 2004. Essential of Managerial Finance. USA. The Dryden Press Harcouff Brace Collage Publishing. 
Darmadji, M. Dan M. Fakhrudin. 2001, Pasar Modal Di Indonesia, Jakarta: Salemba Empat.

Dewi. 2018 Analisis Kinerja Keuangan PT. Mayora Indah Tbk Di Bursa Efek Indonsia, Skripsi, STIM-LPI (Sekolah Tinggi Ilmu Manajemen-Lembaga Pendidikan Indonesia), Makassar.

Destimira Riza. 2016. Pengaruh Kinerja Keuangan Terhadap Harga Saham Terhadap Perusahaan Otomotif dan Komponennya yang Terdaftar di Bursa Efek Indonesia. Skripsi, Fakultas Ekonomi, Universits Bung Hatta.

Fakhruddin dan Sopian Hadianto. 2001. Perangkat dan Model Analisis Investasi di Pasar Modal. Buku satu. Jakarta.

Elex Media Komputindo. Firman Maulana. 2014. Analisis Pengaruh Kinerja Keuangan Terhadap Harga Saham Pada Perusahaan Makanan dan Minuman yang Terdaftar di BEI Periode Tahun 2010-2012.

Halim, Abdul. 2005. Analisis Investasi. Edisi II. Jakarta: Salemba Empat.

Henry Simamora. 2000. Basis Pengambilan Keputusan Bisnis. Jakarta. Salemba Empat.

Hery, 2015 Analisis Laporan Keuangan, CAPS (Center For Academic Publishing Service), Jogjakarta.

Hendra Adhitya Wicaksono. 2013. Pengaruh Current Ratio, Debt to Assets Ratio, Total Assets Turnover, Return On Equity, Suku Bunga, Kurs Valuta Asing, Inflasi, dan Kas Dividen terhadap Harga Saham Perusahaan Makanan dan Minuman Yang Terdaftar di BEI Periode 2009-2011.

M, Irsan Nasarudin. 2007. Aspek Hukum Pasar Modal Indonesia. Jakarta.

Maulana, Firman. 2014. Analisis Pengaruh Kinerja Keuangan Terhadap Harga
Saham Pada Perusahaan Makanan dan Minuman Yang Terdaftar di BEI Periode Tahun 2010-2012. Artikel Ilmiah Mahasiswa 2014.

Masdar Mas'ud. 2010. Analisa Sekuritas Pasar Modal. Makasar.

Pandji Anoraga. 2006. Pengantar Pasar Modal, Jakarta.

Putri, Tiara Rachman, 2011. Analisis Pengaruh Kinerja Keuangan Terhadap Harga Saham Pada Perusahaan Manufaktur di Bursa Efek Indonesia. Jakarta. Jurnal Universitas Gunadarma.

Rika Anggraeni. 2011. Pengaruh Kinerja Keuangan Terhadap Harga Saham Pada Perusahaan Manufaktur yang Terdaftar Di (BEI). Bandung. Jawa Barat. Universitas Komputer Indonesia

Teska Destia Ratri, 2018, Pengaruh Kineeja Keuangan Terhadap Harga Saham Perusahaan Tekstil dan Produk Tekstil yang Terdaftar di Bursa Efek Indonesia. Yogyakarta. Fakultas Ekonomi, Universitas Negeri.

Kasmir, 2009. Analisis Laporan Keuangan. Jakarta: PT Raja Grafindo Persada.

Edisi ke-delapan.

Harmono, 2009. Analisis laporan keuangan. Jakarta: PT Bumi Aksara. Edisi ketiga.

Hendra Adhitya Wicaksono. 2013. Pengaruh Current Ratio, Debt to Assets Ratio, Total Assets Turnover, Return On Equity, Suku Bunga, Kurs Valuta Asing, Inflasi, dan Kas Dividen terhadap Harga Saham Perusahaan Makanan dan Minuman yang Terdaftar di BEI Periode 2009-2011.

S. Munawir. 2009. Manajemen Keuangan. Jakarta: PT Raja Grafindo Persada. Edisi ke-tiga 
Shidiq, Nieke Arwiyati. 2012. Pengaruh EVA, Rasio Profitabilitas dan EPS Terhadap Harga Saham Pada Perusahaan Asuransi yang terdaftar di Bursa Efek Indonesia Tahun 20062010. Semarang. Skripsi. Universitas Diponegoro.

(http://core.ac.uk/download/pdf/11734 130.pdf)

Suad Husnan. 2004. Dasar Dasar Teori Portofolio dan Analisis Sikuritas Yokyakarta. UPP AMP YKPN.

Kasmir. 2000. Analisis Laporan Keuangan. Yogyakarta : Lyberti Yogyakarta. Edisi Ke-empat

M. Fahran. 2016. Pengaruh Kinerja Keuangan Terhadap Harga Saham Terhadap Perusahaan Telekomunikasi Yang Terdaftar di Bursa Efek Indonesia. Skripsi, Fakultas Ekonomi. Makassar. Universitas Islam Negeri Alauddin.

Nieke Arwiyati Shidiq. 2012. Pengaruh EVA, Rasio Profitabilitas, dan EPS Terhadap Harga Saham Pada Perusahaan Asuransi yang Terdaftar di Bursa Efek Indonesia tahun 20062010.
Sitti Nur Hikmah, 2012, Pengaruh Kinerja Keuangan Terhadap Return Saham Terhadap Perusahaan Manufaktur dan Yang Terdaftar di Bursa Efek Indonesia. Skripsi, Fakultas Ekonomi. Makassar. Universitas Hasanuddin.

Syamsul, Muhammad, 2006 Pasar Modal Dan Manajemen Portofolio. Surabaya, Airlangga.

Tiara Rachman Putri. 2011. Analisis Pengaruh Kinerja Keuangan Terhadap Harga

Saham Pada Perusahaan Manufaktur Di Bursa Efek Indonesia.

Website www.idx.co.id

Website www.yahoofinance.co.id

Website www.saham.com

Wicaksono Hendra Adhitya, Hendra. 2013. Pengaruh Current Ratio, Debt To Assets Ratio, Total Assets Turnover, Return On Equity, Suku Bunga, Kurs Valuta Asing, Inflasi, Dan Kas Dividen Terhadap Harga Saham Perusahaan Makanan Dan Minuman Yang Terdaftar Di BEI Periode 2009-2011. 